\title{
Women's Participation in the NREGA: Some Observations from Fieldwork in Himachal Pradesh, Kerala and Rajasthan
}

\author{
Ratna M. Sudarshan, Rina Bhattacharya and Grace Fernandez
}

\begin{abstract}
The broad objective of this study was to understand the reasons behind the wide variations in participation by women in the NREGA and the policy implications that follow. Based on fieldwork in two states where women form a high proportion of the workers, Kerala and Rajasthan, and one where the proportion was low, Himachal Pradesh, emerging policy implications include the need to develop a wider range of activities that acknowledge life cycle issues and bodily ability; in sparsely populated and remote areas a different design or even a cash transfer programme may be better able to meet the objective of assuring minimum income; creation of spaces that allow non-governmental local groups to be participants in implementation and outreach work and not just watchdogs; immediate revision of the schedule of rates and implementing the revised rates to allow better earning, or else payment on a daily wage basis.
\end{abstract}

\section{Context and motivation \\ The National Rural Employment Guarantee Act (NREGA) (now Mahatma Gandhi National Rural Employment Guarantee Act) (Ministry of Rural Development 2005) has completed four years since its implementation. Initially applied to 200 disadvantaged districts, the coverage has since been extended to the entire country. ${ }^{1}$ The NREGA can be viewed as a social protection scheme that provides a floor to rural household income; part of an employment strategy providing work for wages and a stimulant for local economic development through the creation of productive assets.}

The Act provides that priority be given to women in such a way that at least one-third of those who have registered, applied for and been given work, are women. ${ }^{2}$ Across the country, the actual proportion of work days going to women varies considerably. In 2007, at the national level around 43 per cent of the total person work days were provided to women. Out of 26 states, we find 10 states had between 25 and 38 per cent female work days; five states had less than 25 per cent and 11 had over 40 per cent. At the two extremes, we find Jammu and Kashmir with 5 per cent and Himachal with 13 per cent on the one hand and Tamil Nadu with 82 per cent, Tripura with 76 per cent, Rajasthan with 68 per cent and Kerala with 66 per cent on the other. ${ }^{3}$

The broad objective of the study reported here was to understand the reasons behind the wide variations observed in participation by women. To this end, we carried out fieldwork in two states where women form a high proportion of the workers on NREGA worksites, Kerala and Rajasthan, as well as one where the proportion was low, Himachal Pradesh. The intention was to understand both the implementation issues that might be influencing the decision to participate, and to identify relevant factors in the environment and context in which the programme is being implemented. It was expected that the analysis would yield some useful policy implications.

\section{Sampling and methodology}

Fieldwork was carried in areas selected from the first 200 'most backward' districts where NREGA implementation began in 2006. Roughly 
100 people, mainly women, were interviewed in each of the three districts visited. It must be emphasised here that the findings of the study are in no way representative of states or even districts; moreover a special effort was made to include areas with the most remote and difficultto-access terrain, populated by marginalised social groups, and areas that lacked other employment opportunities. In Kerala, the district selected was Palakkad, where over 85 per cent of the population is rural. Fieldwork was carried out in two blocks within this district, Malampuzha (which is largely agricultural and has some industry) and Attapaddy. Almost 40 per cent of the population in Attapaddy is tribal, and severely impoverished. Interviews were conducted with a total of 96 people, some of them male. They included both participants and non-participants in NREGS; Area Development Supervisors in charge of worksite management, NGO workers and government officials. A total of nine villages from seven panchayats were visited. In Himachal, the study was conducted in Sirmour district, Sangrah and Shillai blocks. Sirmour has the highest proportion of scheduled caste households in the state. In both blocks, livelihood strategies are a combination of rainfed agriculture, livestock rearing and seasonal migration. A total of 106 women were interviewed from 13 villages in six gram panchayats (elected village level bodies) in the two blocks. In Rajasthan, the area visited was in Abu Road block in Sirohi district and a survey was carried out of 115 households in two villages, Mahikhera and Nichlagarh. Sirohi is a rain-fed, drought prone area. Some 70 per cent of the inhabitants there are from a tribal community of Garasias.

In each place, there is considerable diversity within the sample. Data was collected through field visits and interviews over the period July 2008 to December 2009. Key findings are reported below.

\section{What explains the observed differences in women's participation in the NREGA?}

The first observation from fieldwork was that many women have been persuaded to come out of the house for work for the first time in response to this programme in both Rajasthan and Kerala. In Malampuzha, Kerala, the scheme has encouraged non-working women, widows and the elderly to participate. The usual routine for these women is to complete household work in the morning and then come to the worksite. Women are attracted by the pay rate, since the minimum wage of Rs 125 being paid on the sites in Kerala is well above the prevalent market wage for women (Rs70-80), but well below that for men (Rs200 or above). In Rajasthan too, the minimum wage of Rs 100 is greater than the prevalent market wage for female unskilled workers. In contrast, in Himachal, market wages for both male and female workers are slightly above the minimum wage of Rs $100 .^{*}$

Second, the level of female work participation in general was just over 15 per cent in Kerala, according to the 2001 Census (Census of India 2001), while in Palakkad, the district studied here, it was a little higher at 21 per cent. However, on NREGA sites in Palakkad, 85 per cent of all applicants given work were women. ${ }^{5}$ In Rajasthan, women's work participation overall stood at around 33 per cent, and in Abu Road at 25 per cent. The share of women in total work days generated by NREGA at state level was almost 70 per cent in 2007, while the ISST survey in 2009 showed that over 50 per cent of women in the two villages visited were participants in NREGA. In Himachal in 2001, the overall female work participation rate was 38 per cent and in Sirmour district, 41 per cent. However, the share of women in work days generated through NREGA in 2007 was low overall, at 13 per cent, and even lower in the district visited, Sirmour, at 3 per cent. ${ }^{6}$ This data for Rajasthan and Kerala suggest that non-working women are being drawn into the workforce, but the same effect is not seen in Himachal.

Even when market wages may approximate that earned on the NREGA sites, work is often not available. Given the distinctive geography of Kerala and the close proximity of rural and urban settlements, workers in Palakkad are able to access work in agriculture, small local factories and services spanning rural and urban areas. Additionally, women have been organised into various micro-enterprises through their Kudumbashree (name of State Poverty Eradication Mission in Kerala) groups. ${ }^{7}$ But in other places, such as the tribal areas in Attappady block, there was no other work - neither forest nor agricultural - available for tribal women.

Similarly in Abu Road, other work is not available within or near the village, so most men and some women commute to work some distance away. 
Third, a feature specific to Kerala is that the sites are managed by women and that most of the women coming for work have already been mobilised into self-help groups, so they had prior experience of working together and an already existing female managerial capacity, both of which help to make NREGA more accessible to women. The Kerala state government has entrusted the line management and implementation of the NREGS to Kudumbashree (the state poverty eradication mission, and a programme that has mobilised women into selfhelp groups for economic activity). The Kudumbashree programme started in urban areas in 1998, and was later extended to rural areas. Women's self-help groups are formed and microenterprises started. The Area Development Society of the Kudumbashree, representing 30-40 'neighbourhood groups" at Ward level, provides a volunteer Area Development Supervisor (ADS) who is placed in charge of the NREGS work and ensures proper maintenance of muster rolls and provision of worksite facilities. The ADS is usually the head of an existing self-help group, and an emergent village leader. The Area Development Supervisor looks after two or three sites, depending on the size of the village. Typically, she is a woman between 30 and 45 years, is educated, and has been associated with Kudumbashree for a few years. In Attapaddy, the Kudumbashree is the first point of contact through which villagers learn about and participate in the programme. Mutual mistrust led to the dissolution of mixed groups of tribal and nontribal members. It was found that tribal illiteracy impairs the spread of awareness about the scheme and some tribal ADSs remain unclear about procedures, even after orientation programmes and trainings. About 100 entirelyadivasi Kudumbashree groups (tribal groups) were created in early 2009 to ease the process of assimilation. According to Chathukalam and Gireesan (2008), NREGA implementation in these tribal communities has been hindered by ignorance of tribal life and faulty targeting.

Fourth, the number of earners in the household is an important factor. In a household with a single earner, wage work with daily payment is preferred and NREGS is not the first option. Where there are two earners, only one can go for NREGS work and given the disparity in market wages, it is usually the woman. The poorest, particularly single women households, prefer daily wage payments to NREGS, where payments are made usually after a month.

Fifth, the management of care and other household responsibilities influences participation in different ways. In Kerala, those who are less visible on site include young women with young children (although fieldwork did not uncover any latent demand from this group for work). In Rajasthan, young children were seen on sites with their mothers, and some young girls looked after younger siblings in the absence of alternative childcare facilities - in some cases staying back from school in order to do so and allow their mothers to work.

In Himachal, traditionally determined gender roles reportedly constrain women from accessing NREGS, especially the time spent by women in collecting fodder for the animals, and the fact that timber, grass and water resources are retreating further uphill. While women do agricultural work in their own fields, it is not the convention for women to work on other people's land. But women from scheduled castes or migrant worker households, do seek out wage work. In one village dominated by an upper caste and another with 'other backward castes', both of which had negligible participation of women in NREGS, women reported that the work was too heavy and they were not comfortable with the idea of lifting stones on the road. However, in the adjacent village dominated by a scheduled caste, women were favourably disposed towards the scheme and during interviews, said they were proud to have bank accounts and spent their earnings primarily on their children and daily household expenses.

In contrast to Kerala and Rajasthan where single women (including widows) might prefer other work; in Himachal, this group was seen to be participating in the NREGA.

\section{What are the implications for households' and women's wellbeing?}

The additional income from the NREGA work improves household wellbeing but also importantly, has enabled women to undertake some personal expenditure - such as the purchase of clothes or lunch boxes (proudly displayed by women in Rajasthan to the research team) for their own use. The actual impact depends crucially on the wages paid and the 
number of days of work generated. Fieldwork showed that in Kerala and Himachal, workers were paid the minimum wage for the number of days worked. There was no uncertainty regarding the payment that was earned and due. In contrast, in Rajasthan, the payment was linked to tasks completed. Workers were paid on the basis of a simple formula of value of work completed divided by the number of workers. There was room for uncertainty on both counts: workers did not know in advance how much work needed to be done in order for them to be eligible for the minimum wage; and there were names on the muster rolls of persons not actually present at the worksite. While the Rajasthan model is often flagged as 'good practice' because it seeks to link earning to effort and productivity, the actual outcome of very low wage payments for very hard work is not acceptable. It needs to be considered whether the practice of payment by daily norm is not superior in its wellbeing impact.

The other aspect is the number of days of work generated. None of the states has been able to assure households of 100 days of work and in practice, an informal rotation system is followed with the available work being shared out among applicant households. For example, the average number of days generated per household was around 35 in Palakkad, Kerala at the time of the study. The field survey in Abu Road, Rajasthan found that around 30 per cent of households received less than 50 days of work, while 70 per cent received more.

Fieldwork did not reveal any changes in the allocation of household responsibilities as a result of women's participation in this work. An unintended outcome is the large presence, observed in Rajasthan, of young children on worksites. Children accompany women to the worksites; sometimes help with sibling care and at times, were seen to be working in lieu of other members of the household. The one place where the fieldwork found a reasonably well functioning crèche facility was in the tribal block in Kerala where an ayah (nanny) was observed to be looking after four young children. In Himachal, in the gram panchayat, which reported the highest participation of women in the block, nearness to home was cited as a crucial factor in attracting so many women to the site, since women could work without worrying about their children. Some lived as close as 250 metres from the site and even went off to milk cows and have lunch in the middle of work. Children were mostly left in neighbours' houses. Women reported for work after finishing household chores, feeding the animals and weeding in the fields.

In Abu Road, Rajasthan, while all the women we interviewed said that they had a bank or post office account in their own name where the wages were deposited, only 38 per cent said that they were able to decide themselves how to use these earnings. In Kerala, the programme office reported that 40 per cent of the earnings were not immediately withdrawn from the bank, and women reported using the money for specific 'bulky' expenses. ${ }^{9}$ In Rajasthan, similarly, almost one-fifth of women respondents reported adding to household assets or paying back loans.

\section{What is the role of existing institutions in explaining the observed outcomes?}

As per the Act and its operational guidelines, the panchayats are responsible for providing information, registering workers and supervising works and payment. In Kerala, the panchayat works closely with the Kudumbashree system and with this non-conflictive partnership, the implementation has been generally smooth. But in Himachal and Rajasthan, it was seen that women did not usually attend panchayat meetings, although there were female-headed panchayats and the mandatory number of female panchayat members. The mahila mandals in Himachal (women's groups which are not linked to the government, unlike the groups in Kerala) have not attempted either to contribute to disseminating awareness about the NREGA or auditing the programme. Their activities in the villages are usually restricted to kitchen gardening, goat rearing, etc.

In Abu Road, Rajasthan, an NGO had facilitated the organising of youth groups. It was seen that these groups kept up a continuous scrutiny of the panchayat's work, with active contestation in case of irregularities. Thus, the presence of informal organised groups in Rajasthan appears to have a watchdog effect and improve the functioning of the formal institutional structure.

In the Kerala context, decentralisation has a long history. The People's Campaign in Kerala, evolving in the wake of the 73rd and 74th Constitutional Amendments (1992-3), generated 
large scale decentralisation and devolution of powers to local governing bodies. The state's capacity for public mobilisation combined with its achievements in both male and female literacy, placed it in a position to make village planning successful (Sharma 2003). Often, in other parts of the country, resources are distributed across departments and allocated to specific schemes, leaving little flexibility to design programmes at village or panchayat level. However, in Kerala, a convergence of schemes and resources from different government departments and programmes has been possible, allowing micro-level development planning. The parallel but linked Kudumbashree organisation has meant that there is a strong effective presence of women in village-level bodies.

While the panchayat structures in the other states exercise formal control over the programme, they cannot wholly determine its outcomes. An absence of technical input during gram sabha (village assembly) proceedings was also reported in Himachal as adversely affecting the scheme, as there was no-one to assess the proposed works' technical practicability and financial requirements, given the NREGA's restricted means. The role of district officials is significant. In particular, the segments of the population that are not well integrated into society are the ones who might find the formal institutional structure especially unfriendly, e.g. migrant, nonHimachalis in Himachal, who do not own land as the local population does. Their ability to access NREGS depends as much on the commitment and ability of government officials to reach out proactively as on their constitutional right to 'demand' work from the panchayats.

One of the changes made (since September 2008) to the NREGA implementation is the requirement that all payments be made into individual bank or post office accounts. In Himachal, it was observed that NREGA wages were being paid into a bank that was approximately eight kilometres away from the village. Villagers were forced to spend a whole working day travelling to the bank, queuing and collecting the payment and ensure they were there during banking hours. While in Kerala, no problems were reported relating to bank payments during the fieldwork, in Rajasthan over 70 per cent of the respondents said they faced delays in payment while withdrawing money from the post office. Other problems related to distance of the post office, and filling out forms, since the help of literate persons would be required (for other similar assessments of NREGA banking experience, see also Siddhartha 2008; Adhikari and Bhatia 2010).

\section{In what ways does the NREGA appear to be having a wider impact?}

Results from the Kerala fieldwork suggest that the regular implementation of the NREGS has led to some upward movement of female unskilled wages. Women reported earning only Rs 70-80 per day from agricultural work prior to NREGA - a wage which had increased, although the level varies from place to place. Given the higher wages on NREGS sites, there is also an emerging shortage of female workers for agricultural work. The response to this shortage has taken two forms. In some areas, NREGS works are kept open only when agricultural work is not available. Thus, one panchayat has developed a work calendar. Six months are set aside for NREGS works (March-June and November-December) and six months for agricultural work (July-October and January-February). This prevents clashes and consequent labour shortages and wage fluctuations, and ensures year-round employment. In another area, rubber and coconut plantation owners were forced to raise the daily agricultural wage to keep labourers away from NREGS worksites after a request to the panchayat to cease works during the harvesting season went unheeded. Whether the upward pressure on female wages will have any effect on gender wage gaps will depend on the trend of men's wages, which could not be ascertained by this study.

Another impact expected from NREGA's successful implementation, is a reduction in distress migration from the villages. Although some households or individuals may migrate long distances to other states, the dominant type of migration observed was short distance migration to neighbouring urban or periurban areas. Fieldwork in Abu Road was able to explore this aspect to some extent and it emerged that such migration continues, with 40 per cent of the households reporting migrant members in December 2009. Men continue to migrate, although women access work on NREGA. Similarly, no evidence was seen in Himachal that 
the NREGA had an impact in stalling intra-state migration, although there was sufficient labour demand when works were ongoing. In the area surveyed in Kerala, there was seen to be a similar process of migration to neighbouring areas, again largely by men.

The objective of the NREGA is both to provide an income transfer to those dependent on agriculture without other means of earning a living, and to create useful local assets which in turn will stimulate local development. The work, as observed through our fieldwork, largely engages in creating useful but temporary assets. These include roads and various forms of storing rain water. Many structures do not last beyond one rainy season.

\section{Emerging implications and policy choices}

The composition of women workers seen on worksites, and the nature of the work offered, suggests that there is a need to give some serious thought to developing a wider range of activities under the NREGA. For example, while elderly women and young women with infants coming to sites confirms their need to earn a wage, hard manual labour is not desirable from the point of view of their own health or that of their infants. The design of the programme needs to accommodate these variations in life cycle and physical ability to undertake the hard manual labour.

The programme design includes a recommendation that crèches be opened at worksites. Fieldwork confirms that it is only in rare instances that a crèche is seen, and even when there is a facility, it is of a very minimal nature. The question of childcare needs to be discussed more widely and a menu of choices offered: as suggested above, can women with infants be offered work other than hard manual labour? And indeed, looking after other young children would be one such alternative. Would young children not needing to be breastfed be better looked after nearer the home than at worksites?

It has been noticed that in states where there is a high density of population and a tradition of wage work by women, NREGA has been able to draw out large numbers of women. But in areas where this is not the case - and this includes the areas where tribal populations live deep inside the forest as in Kerala, or a state like Himachal, where the population is very dispersed and scattered, the combined effect of these factors leads one to question whether public works are the best way of ensuring a basic income, or whether some other form of conditional cash transfers might be more suitable.

Linked to this is the likely impact of different kinds of assets created through NREGA. At its best, NREGA could act as a catalyst and set in motion a virtuous cycle of development. It is important, then, that the assets being created are embedded in the existing local economic activity and the social framework. It is presumed in the programme design that the central role given to the gram panchayat ensures such embeddedness. Given the observation that women do not actively participate - with some exceptions - and that there are other, informal institutions in villages that have evolved in various ways, a suggestion from our fieldwork is that the programme design would benefit if more spaces were created for the engagement of other non-governmental local groups (local youth, women's groups), not just as watchdogs but as contributors of ideas for projects, and as participants in implementation and outreach work.

The potential of the programme for allowing women to make some savings was observed everywhere. Facilitating their ability to save toward specific purchases through easily accessible bank accounts is a way of enhancing wellbeing. At present, even when money is deposited in a bank or post office, access is often difficult, making frequent withdrawals inconvenient, and hence encouraging withdrawal of the full amount. Better systems of mobile banking could improve this situation.

Finally, over the last four years, the difference between minimum wages payable and actual wages received has persisted in Rajasthan. There is an urgent need to immediately revise the schedule of rates and implement the revised rates to allow better earning, or else pay on a daily wage basis. 


\section{Notes}

* Apart from the authors, Madhuri Karak and Geraldine Fernandez contributed to the fieldwork. Thanks are due to Naila Kabeer, Ashwani Saith and Jayati Ghosh and participants at SPA meetings, for their comments; usual caveats apply.

1 The Act was promulgated in 200 districts in the first phase with effect from 2 February, 2006 and then extended to an additional 130 districts in the financial year 2007-08. The remaining districts were included in the NREGA with effect from 1 April 2008.

2 For details on implementation guidelines, see Operational guidelines on the official website: nrega.nic.in

3 Data for 2007, accessed January 2008, from NREGA website at: http://nrega.nic.in/

4 The data on wages is as observed in the field. The relation between minimum and market

\section{References}

Adhikari, A. and Bhatia, K. (2010) 'NREGA Wage Payments: Can We Bank on the Banks?', Economic and Political Weekly, 2 January: 30-7

Census of India (2001) Districts Profiles, http://censusindia.gov.in/ (accessed 15 January 2010)

Chathukulam, Jos and Gireesan, K. (2008) 'Employment to the Tribal Communities under NREGS: A Case from Wayanad, Kerala', impact assessment study sponsored by Ministry of Rural Development, Government of India, presented at International Conference on Employment Opportunities and Public Employment Policy in Globalising India, Centre for Development Studies, Trivandrum, 3-5 April 2008 wages across states is also confirmed in Chavan and Bedamatta (2006).

5 Data for 2007-08, available from the programme office.

6 It should be noted that overall, the share of women in person-days has gone up since then in Himachal, but in Sirmour district it remains close to 4 per cent.

7 Self-help groups of 8-10 women organised for savings and micro-enterprises.

8 Neighbourhood groups typically consist of all women in a neighbourhood; several self-help groups with 8-10 women - each may be formed out of one neighbourhood group.

9 Note on NREGS Best Practices, Palakkad District, available from the Programme Coordinator.

Chavan, P. and Bedamatta, R. (2006) 'Trends in Agricultural Wages in India 1964-65 to 1999-2000', Economic and Political Weekly, 23 September: 4041-51

Ministry of Rural Development (2005) National Rural Employment Guarantee Act 2005: Operational Guidelines, http://nrega.nic.in/Nrega_ guidelines.pdf (accessed 15 December 2008) Sharma, R. (2003). 'Kerala's Decentralisation: Idea in Practice' Economic and Political Weekly, 6 September: $3832-50$

Siddhartha, Vanaik A. (2008) 'Bank Payments: End of Corruption in NREGA?', Economic and Political Weekly, 26 April: 33-9 